H.S.L. Moseley FFarCs,

K. Bhavani Shankar MBBS MD,

A. Krishnan MBBS DA

\title{
Flow requirements for the Bain breathing circuit during anaesthesia for Caesarean section
}

We studied the relationship between arterial carbon dioxide tension $\left(\mathrm{PaCO}_{2}\right)$ and fresh gas flow (FGF) during use of the Bain breathing circuit for Caesarean section anaesthesia. Thirty-one patients undergoing Caesarean section were anaesthetised using the Bain circuit with intermittent positive pressure ventilation. The $\mathrm{PaCO}_{2}$ were measured at FGF of $70 \mathrm{mi} \cdot \mathrm{kg}^{-1} \cdot \mathrm{min}^{-1}, 80$ $\mathrm{ml} \cdot \mathrm{kg}^{-1} \cdot \mathrm{min}^{-1}$, and $100 \mathrm{ml} \cdot \mathrm{kg}^{-1} \cdot \mathrm{min}^{-1}$. The FGF requirement to maintain a given $\mathrm{PaCO}_{2}$ during Caesarean section anaesthesia is the same as the requirements for nonpregnant subjects, despite the increase in carbon dioxide production associated with pregnancy. This is prabably because the total FGF determined by body weight and given during Caesarean section anaesthesia is 15-20 per cent higher than nonpregnant levels, due to the weight gain associated with pregnancy. A FGF of $100 \mathrm{ml} \cdot \mathrm{kg}^{-1}$ of pregnant weight/min maintains $\mathrm{PaCO}_{2}$ of $4.44 \mathrm{kPa}$ predelivery, which is in the desirable range of $\mathrm{PaCO}_{2}$ during Caesarean section.

\section{Key words}

ANAESTHESIA: obstetrics; EQUIPMENT: Bain breathing circuit; MEASUREMENr: arterial carbon dioxide tension.

From the Department of Anaesthesia and Intensive Care, University of West Indies, Queen Elizabeth Hospital, Barbados - where correspondence should be addressed to Dr. Moseley.
The Bain breathing circuit ${ }^{\circledR}$ which is a modified version of the Mapelson D circuit was described by Bain and Spoerel in 1972.' Since then it has been used extensively in children and adults. With controlled ventilation, a fresh gas flow (FGF) of $70 \mathrm{ml} \cdot \mathrm{kg}^{-1} \cdot \mathrm{min}^{-1}$ produces normocarbia and FGF of $100 \mathrm{ml} \cdot \mathrm{kg}^{-1} \cdot \mathrm{min}^{-1}$ produces hypocarbia. ${ }^{2,3} \mathrm{An}$ inverse relationship has been demonstrated between the FGF rate and arterial carbon dioxide tension $\left(\mathrm{PaCO}_{2}\right){ }^{2-4}$ As the $\mathrm{PaCO}_{2}$ can be predicted for a given FGF, the Bain breathing circuit has been suggested as the anaesthetic system to be used to maintain a predictable $\mathrm{PaCO}_{2}$ during Caesarean section anaesthesia. ${ }^{4}$

Pregnancy is associated with increased carbon dioxide $\left(\mathrm{CO}_{2}\right)$ production. ${ }^{5-12}$ It has been suggested therefore that higher fresh gas flows are required to maintain a given $\mathrm{PaCO}_{2}$, compared with nonpregnant subjects. ${ }^{4}$ Kneeshaw et al . determined FGF requirements for Caesarean section anaesthesia using the Bain circuit, based on the end-tidal carbon dioxide tensions $\left.(\mathbf{P E C O})_{2}\right)$. They assumed $\mathrm{PaCO}_{2}$ to be higher by $0.67 \mathrm{kPa}$ and suggested that a FGF of $120 \mathrm{ml} \cdot \mathrm{kg}^{-1} \cdot \mathrm{min}^{-1}$ is necessary to maintain $\mathrm{PECO}_{2}$ at $4.16 \mathrm{kPa}$ and $\mathrm{PaCO}_{2}$ at $4.83 \mathrm{kPa}^{4}$ Since we found no report that evaluated the relationship between FGF and $\mathrm{PaCO}_{2}$ during Caesarean section anaesthesia using the Bain circuit we undertook the following study.

\section{Methods}

The study was approved by the Medical Ethics Committee of Queen Elizabeth Hospital and informed consent was obtained from all patients.

Thirty-one patients coming for elective or emergency Caesarean section were selected for the study. None of the subjects had any pre-existing 
TABLE 1 Mean values ( \pm SEM) for pre- and post-delivery $\mathrm{PaCO}_{2}$ and $\mathrm{pH}$ in the three groups

\begin{tabular}{lllll}
\hline & & $\begin{array}{l}\text { Group A } \\
F G F=70 \mathrm{ml} \cdot \mathrm{kg} \cdot \mathrm{min}^{-1}\end{array}$ & $\begin{array}{l}\text { Group B } \\
F G F=80 \mathrm{ml} \cdot \mathrm{kg} \cdot \mathrm{min}^{-1}\end{array}$ & $\begin{array}{l}\text { Group C } \\
F G F=100 \mathrm{ml} \cdot \mathrm{kg} \cdot \mathrm{min}^{-1}\end{array}$ \\
\hline $\mathrm{PaCO}_{2}(\mathrm{kPa})$ & predelivery & $4.76 \pm 0.11$ & $4.60 \pm 0.09$ & $4.44 \pm 0.11$ \\
& postdelivery & $4.59 \pm 0.08$ & $4.38 \pm 0.19$ & $4.34 \pm 0.12$ \\
$\mathrm{pH}$ & predelivery & $7.373 \pm 0.01$ & $7.420 \pm 0.01$ & $7.434 \pm 0.01$ \\
& postdelivery & $7.370 \pm 0.02$ & $7.400 \pm 0.01$ & $7.417 \pm 0.01$ \\
\hline
\end{tabular}

$\mathrm{p}<0.05$ Group A versus Group $\mathrm{C}$.

$\mathrm{p}=\mathrm{ns}$ Group A versus Group B

$p=n s$ Group B versus Group C.

cardiovascular or respiratory disorder and they had never smoked.

The patients were given $30 \mathrm{ml}$ of magnesium trisilicate* half an hour prior to surgery. Anaesthesia was induced with the patient in 15 degrees left lateral tilt after pre-oxygenation with 100 per cent oxygen using a Bain breathing circuit for about five minutes prior to induction of anaesthesia. Induction was with thiopentone $5 \mathrm{mg} \cdot \mathrm{kg}^{-1}$ and the patients were intubated after succinylcholine $100 \mathrm{mg}$ with a cuffed endotracheal tube, with use of cricoid pressure. Anaesthesia was maintained with pancuronium $0.08 \mathrm{mg} \cdot \mathrm{kg}^{-1}, 50$ per cent oxygen in nitrous oxide and 0.5 per cent halothane until the baby was delivered, and afterwards with 33 per cent oxygen in nitrous oxide and narcotic analgesic supplements.

Controlled ventilation was performed with a Bird mark 4A ventialtor. The tidal volume was maintained at $12 \mathrm{ml} \cdot \mathrm{kg}^{-1}$ using a Wright spirometer. The respiratory rate was $12 / \mathrm{min}$ (minute expiratory volume $=144 \mathrm{ml} \cdot \mathrm{kg}^{-1} \cdot \mathrm{min}^{-1}$ ). The patients were divided at random into three groups. Group A (ten patients) received a FGF of $70 \mathrm{ml} \cdot \mathrm{kg}^{-1} \cdot \mathrm{min}^{-1}$, Group B (ten patients) $80 \mathrm{ml} \cdot \mathrm{kg}^{-1} \cdot \mathrm{min}^{-1}$ and Group C (11 patients) $100 \mathrm{ml} \cdot \mathrm{kg}^{-1} \cdot \mathrm{min}^{-1}$.

Arterial samples were drawn from a radial artery just before uterine incision and approximately 35 minutes after induction (post delivery). The arterial samples were analysed immediately in a Corning blood gas analyser (model 165/2) for $\mathrm{PaCO}_{2}$ after two-point calibration before every sample. The induction-delivery time, uterine incision-delivery

*At the time of the study, it was the practice in our hospital to use magnesium trisilicate as antacid before Caesarean section, but it now has been replaced with sodium citrate. time and Apgar scores were noted. The nasopharyngeal temperature of the patients was monitored and blood gas results were corrected for the body temperature.

Student's t test was used to compare mean values of $\mathrm{PaCO}_{2}, \mathrm{pH}$, age, weight, induction-delivery interval and uterine incision-delivery interval among the groups.

The relationship between FGF rate $\mathrm{ml} \cdot \mathrm{kg}^{-1} \cdot \mathrm{min}^{-1}$ (x) and $\mathrm{PaCO}_{2}$ (y) was studied with regression analysis (both linear and curvilinear).

Apgar scores were compared among the groups using non-parametric statistics (Mann-Whitney test).

The mean pre- and post-delivery $\mathrm{PaCO}_{2}$ and $\mathrm{pH}$ values in each group were compared with a paired ' $t$ ' test.

\section{Results}

Table I shows mean pre- and post-delivery $\mathrm{pH}$ and $\mathrm{PaCO}_{2}$ values in the three groups. The mean ages, weights, Apgar scores, induction-delivery intervals and uterine incision delivery intervals are presented in Table II.

The mean $\mathrm{PaCO}_{2}$ at a FGF of $70 \mathrm{ml} \cdot \mathrm{kg}^{-1} \cdot \mathrm{min}^{-1}$ was $4.76 \pm 0.11 \mathrm{kPa}$ before delivery and $4.59 \pm$ $0.08 \mathrm{kPa}$ following delivery. For FGF of 80 $\mathrm{ml} \cdot \mathrm{kg}^{-1} \cdot \mathrm{min}^{-1}$, the pre- and post-delivery $\mathrm{PaCO}_{2}$ values were $4.60 \pm 0.09 \mathrm{kPa}$ and $4.38 \pm 0.19 \mathrm{kPa}$ respectively. At $100 \mathrm{ml} \cdot \mathrm{kg}^{-1} \cdot \mathrm{min}^{-1}$ of FGF, the $\mathrm{PaCO}_{2}$ was $4.44 \pm 0.11 \mathrm{kPa}$ pre-delivery and 4.34 $\pm 0.12 \mathrm{kPa}$ post-delivery. There was a statistically significant difference between the $\mathrm{PaCO}_{2}$ and $\mathrm{pH}$ values of the Group A and Group $C$ patients ( $p<$ $0.05)$.

Regression analysis of $\mathrm{FGF}$ rate (x) and $\mathrm{PaCO}_{2}$ (y) showed that the $\mathrm{PaCO}_{2}$ varied inversely with FGF rate delivered to the system $(r=0.248, p<$ 
TABLE II Mean ( \pm SEM) values for ages, weights, induction-delivery intervals, uterine-incision delivery intervals and Apgar scores in the three groups

\begin{tabular}{lccc}
\hline & $\begin{array}{l}\text { Group A } \\
F G F=70 \mathrm{ml} \cdot \mathrm{kg} \cdot \mathrm{min}^{-1}\end{array}$ & $\begin{array}{l}\text { Group B } \\
F G F=80 \mathrm{ml} \cdot \mathrm{kg}^{\prime} \mathrm{min}^{-1}\end{array}$ & $\begin{array}{c}\text { Group C } \\
F G F=100 \mathrm{ml} \cdot \mathrm{kg} \cdot \mathrm{min}^{-1}\end{array}$ \\
\hline Age (years) & $25.50 \pm 1.31$ & $27.70 \pm 1.70$ & $27.4 \pm 1.47$ \\
Weight (kgs) & $74.92 \pm 3.70$ & $71.15 \pm 4.04$ & $76.48 \pm 3.17$ \\
Induction-delivery interval (min) & $7.90 \pm 0.28$ & $8.20 \pm 0.30$ & $8.09 \pm 0.30$ \\
Uterine-incision interval (sec) & $51.50 \pm 1.07$ & $50.00 \pm 0.75$ & $49.54 \pm 1.06$ \\
Apgar scores & 8 & 9 & 9.5 \\
\hline
\end{tabular}

$0.05)$. Linear analysis produced a better "fit" than curvilinear.

There was no significant difference between preand post-delivery $\mathrm{PaCO}_{2}$ and $\mathrm{pH}$ values in each group (paired $t$ test). There were no significant differences between the groups with regard to mean age, weight, induction-delivery interval, uterine incision-delivery interval and Apgar score.

\section{Discussion}

The fresh gas flow (FGF) requirements for the Bain breathing circuit for controlled ventilation during anaesthesia for nonpregnant subjects has been evaluated by several workers..$^{1-3}$ Henville and Adams suggested that a FGF of $70 \mathrm{ml} \cdot \mathrm{kg}^{-1} \cdot \mathrm{min}^{-1}$ produces normocarbia $5.44 \pm 0.57 \mathrm{kPa}( \pm \mathrm{SD})$ ranging from $4.05-6.53 \mathrm{kPa}$, and a FGF of 100 $\mathrm{ml} \cdot \mathrm{kg}^{-1} \cdot \mathrm{min}^{-1}$ produces moderate hypocarbia of $4.57 \pm 0.60 \mathrm{kPa}( \pm S D)$ ranging from $3.46-$ $5.98 \mathrm{kPa}^{2}$ Bain and Spoerel found that a FGF of $70 \mathrm{ml} \cdot \mathrm{kg}^{-1} \cdot \mathrm{min}^{-1}$ maintains an arterial carbon dioxide tension $\left(\mathrm{PaCO}_{2}\right)$ of $4.88 \pm 0.57 \mathrm{kPa}( \pm \mathrm{SD})$ ranging from $4.0-6.53 \mathrm{kPa} .^{3}$

Our data show that during Caesarean section anaesthesia, a FGF of $70 \mathrm{ml} \cdot \mathrm{kg}^{-1} \cdot \mathrm{min}^{-1}$ maintains a $\mathrm{PaCO}_{2}$ of $4.76 \mathrm{kPa}$ (range $4.17-5.37 \mathrm{kPa}$ ) before delivery and $4.59 \mathrm{kPa}$ (range 4.13-5.05) after delivery. These figures are similar to those suggested by Bain and Spoerel. ${ }^{3}$ A FGF of 100 $\mathrm{ml} \cdot \mathrm{kg}^{-1} \cdot \mathrm{min}^{-1}$ resulted in a $\mathrm{PaCO}_{2}$ of $4.44 \mathrm{kPa}$ (range 3.85-4.92) pre-delivery and $4.34 \mathrm{kPa}$ (range 3.52-5.07) post-delivery. Again, these agree closely with the results of Henville and Adams. ${ }^{2}$ There was also an inverse relationship between FGF $\mathrm{ml} \cdot \mathrm{kg}^{-1} \cdot \mathrm{min}^{-1}$ and $\mathrm{PaCO}_{2}$ during Caesarean section anaesthesia. A similar relationship has already been demonstrated in nonpregnant patients during anaesthesia with the Bain breathing circuit. ${ }^{2,3}$

Therefore, our study shows that, despite the increase in carbon dioxide production during pregnancy, the FGF based on body weight need not be higher in patients undergoing Caesarean section than in nonpregnant patients to maintain a given $\mathrm{PaCO}_{2}$ with the Bain circuit, during controlled ventilation. The magnitude of the increase in $\mathrm{CO}_{2}$ production during pregnancy is difficult to measure accurately since $\mathrm{CO}_{2}$ output varies from minute to minute. ${ }^{5}$ However, it is likely to be proportional to the increase in oxygen consumption which is 10-20 per cent higher than prepregnancy levels. ${ }^{5-12}$ There is an average weight gain of $13 \mathrm{~kg}$ (range: $8-17$ ) or 10-20 per cent over prepregnant weight. $7,8,10$ Therefore the total FGF based on pregnant body weight increases by $10-20$ per cent over the prepregnant values. Since the magnitude of the increases in $\mathrm{CO}_{2}$ production and total FGF are likely to be similar, a higher FGF $\left(\mathrm{ml} \cdot \mathrm{kg}^{-1} \cdot \mathrm{min}^{-1}\right)$ is not required to maintain a given $\mathrm{PaCO}_{2}$ during Caesarean section anaesthesia using the Bain circuit and controlled ventilation.

Keenan and Boyan ${ }^{13}$ suggested that variations in physiological dead space would affect the efficiency of FGF in the Bain breathing circuit during controlled ventilation. When physiological dead space is reduced, a lower FGF $\left(\mathrm{ml} \cdot \mathrm{kg}^{-1} \cdot \mathrm{min}^{-1}\right)$ is required to maintain a given $\mathrm{PaCO}_{2} \cdot{ }^{13}$ Fisher and Prys-Roberts found a low physiological dead space (0.19) during the first stage of labour. ${ }^{14}$ However, during Caesarean section anaesthesia, the physiological dead space was variable, ranging from $0.19-0.53$, with a mean of $0.30 .^{15}$ This may be due to many factors such as changes in blood pressure, pulmonary blood flow, variations in pulmonary compliance, anaesthetic agents and surgical position, all of which can affect physiological dead space. ${ }^{16-21}$ Therefore it is difficult to predict the effect of physiological dead space on FGF requirements. ${ }^{13}$ This could probably be one of the factors 
contributing to the low correlation between FGF $\left(\mathrm{ml} \cdot \mathrm{kg}^{-1} \cdot \mathrm{min}^{-1}\right)$ and $\mathrm{PaCO}_{2}(\mathrm{r}=0.248)$ in our study.

At term, the $\mathrm{PaCO}_{2}$ has been found to be $4.26-4.53 \mathrm{kPa}^{7-11,22}$ and the $\mathrm{pH}$ to be 7.40 $7.44 .^{3,8}$ The ideal anaesthetic technique should attempt to achieve a $\mathrm{PaCO}_{2}$ of $4.26-4.53 \mathrm{kPa}$ as the best results are obtained when maternal $\mathrm{PaCO}_{2}$ is near preoperative levels. ${ }^{7,22,23}$ Our study shows that a FGF of $100 \mathrm{ml} \cdot \mathrm{kg}^{-1} \cdot \mathrm{min}^{-1}$ (pregnant weight) produces the desirable maternal $\mathrm{PaCO}_{2}$ of $4.44 \pm$ $0.11 \mathrm{kPa}( \pm \mathrm{SE})$ before delivery and $4.34 \pm$ $0.12 \mathrm{kPa}( \pm \mathrm{SE})$ after delivery, during Caesarean section anaesthesia with the Bain circuit with controlled ventilation.

Kneeshaw $e t$ al. advised a higher FGF of $120 \mathrm{ml} \cdot \mathrm{kg}^{-1} \cdot \mathrm{min}^{-1}$ to achieve a maternal $\mathrm{PaCO}_{2}$ of $4.83 \mathrm{kPa}$ and end-tidal carbon dioxide $\left(\mathrm{PECO}_{2}\right)$ of $4.16 \mathrm{kPa}$. They based their study on $\mathrm{PECO}_{2}$ measurement and assumed the $\mathrm{PaCO}_{2}$ to exceed $\mathrm{PECO}_{2}$ by $0.67 \mathrm{kPa}$. This assumption was based on the findings of Nunn et al. in nonpregnant subjects during general anaesthesia. ${ }^{24}$ This assumption does not apply during Caesarean section anaesthesia. The $\mathrm{PaCO}_{2}$ was very close to $\mathrm{PECO}_{2}$ and in 50 per cent of instances the (a-É) $\mathrm{PCO}_{2}$ was negative ${ }^{25}$ Therefore the FGF recommended by Kneeshaw et al. could be higher than required. Further, Raemer et al. concluded that estimation of $\mathrm{PaCO}_{2}$ from monitored $\mathrm{PECO}_{2}$ may not be reliable, as deviations up to $1.06 \mathrm{kPa}$ were common in (a-E) $\mathrm{PCO}_{2}$ values during the course of anaesthesia. ${ }^{21}$

In conclusion, there was an inverse relationship between FGF and $\mathrm{PaCO}_{2}$ during anaesthesia for Caesarean section using the Bain breathing circuit with controlled ventilation. A FGF of $100 \mathrm{ml} \cdot \mathrm{kg}^{-1}$ of pregnant weight/min produces a matemal $\mathrm{PaCO}_{2}$ which is in the desirable range of $4.26-4.53 \mathrm{kPa}$ during Caesarean section anaesthesia.

\section{Acknowledgements}

The authors gratefully acknowledge Dr. P. Seshagiri Rao, for his assistance in statistical evaluation of the results. We also wish to thank the members of Obstetrics Department of the Queen Elizabeth Hospital for their cooperation.

\section{References}

1 Bain JA, Spoerel WE. A streamlined anaesthetic system. Can Anaesth Soc J 1972; 19: 426-35.

2 Henville JD, Adams AP. The Bain anaesthetic system. Anaesthesia 1976; 31: 247-56.

3 Bain $J A$, Spoerel WE. Flow requirements for a modified Mapelson D system during controlled ventilation. Can Anaesth Soc J 1973; 20: 629-36.

4 Kneeshaw ID. Harvey $P$, Thomas TA. A method for producing normocarbia during general anaesthesia for Caesarean section. Anaesthesia 1984; 39: 922-5.

5 Rhodes $P$. Respiration. In: Reproductive Physiology for Medical Students. London: J. \& A. Churchill Ltd. 1969; 168-70.

6 Sutavik SB. Pulmonary disease. In: Medical Complications During Pregnancy. Burrow GN, Ferris TF, editors. Toronto: W.B. Saunders, 1975; 549-57.

7 Cohen SE. Why is the pregnant patient different? Seminars in anesthesia 1982; 1: 273-81.

8 Bonica JJ. Physiology of pregnancy. In: Principles and Practice of Obstetric Analgesia and Anesthesia. Philadelphia: F.A. Davis Co., 1967; 13-39.

9 Aladjem S. Physiology of pregnancy. In: Obstetrical practice. Toronto: The C.V. Mosby Company, 1980; 64-77.

10 Clayton SG. Changes in maternal anatomy and physiology during pregnancy. In: Obstetrics. London: 1975; 47-8.

11 Gutsche $B B$. Matemal physiologic alterations during pregnancy, In: Anaesthesia for Obstetrics. Shnider SM, Levinson G, editors. Baltimore: Williams \& Wilkins, 1979; 254-75.

12 Garrey MM, Govan ADTC, Hodge CH, Callender R. Matemal physiology. In: Obstetrics Illustrated. London: Churchill Livingstone, 1972; 21-46.

13 Keenan $R L$, Boynan $C P$. How rebreathing anaesthetic system control $\mathrm{PaCO}_{2}$. Studies with a mechanical and a mathematical model. Can Anaesth Soc J 1978; 25: 117-21.

14 Fisher A, Prys-Roberts C. Matemal pulmonary gas exchange (a study during normal labour and extradural blockade). Anaesthesia 1968; 23: 350-6.

15 Lyons G, Tunstall ME. Maternal blood gas tensions $\left(\mathrm{PAO}_{2}-\mathrm{PaCO}_{2}\right)$, physiological shunt and VD/VT during general anaesthesia for Caesarean section. Br J Anaesth 1979; 51: 1059-62.

16 Scott $D B$, Lees $M M$, Daute $I T$, Slawson $K B$, Kerr $M G$. Observations in cardiorespiratory function 
during Caesarean section. Br J Anaesth 1969; 41: 489-95.

17 Lees MM, Kerr MG, Scott DB, Taylor SH. Circulatory effects of supine posture in late pregnancy. Clinical Sciences 1967; 32: 453-7.

18 Scott $D B$. Inferior venacaval occlusion in late pregnancy and its importance in anaesthesia. $\mathrm{Br} \mathrm{J}$ Anaesth 1968; 40: 120-8.

19 Farmen $J V$, Thorpe $M H$. Compliance changes during Caesarean section. $\mathrm{Br}$ J Anaesth 1969; 41 : 999-1001.

20 Toldy $M$, Scott $D B$. Blood loss during Caesarean section general anaesthesia. Br J Anaesth 1969; 41: 868-73.

21 Raemer DB, Francis D, James JH, Gabel RA. Variations in $\mathrm{PaCO}_{2}$ between arterial blood and peak expired gas during anesthesia. Anesth Analg 1983; 62: 1065-9.

22 Doughty A. Anaesthesia for operative obstetrics and gynaecology. In: A Practice of Anaesthesia. Churchill Davidson HC, editor. London: Lloyd Luke, $1978 ; 1373$.

23 Shnider SM, Levinson G. Anesthesia for Cesarean section. In: Anesthesia for Obstetrics. Baltimore: Williams \& Wilkins 1979; 262-3.

24 Nunn JF, Hill DW. Respiratory dead space and arterial to end-tidal $\mathrm{CO}_{2}$ tension difference in anesthetized man. J Appl Physiol 1960; 15: 383-9.

25 Shankar KB, Moseley H. Kumar Y, Vemula $V$. Arterial to end-tidal carbon dioxide tension difference during Caesarean section anaesthesia. Anaesthesia 1986; in press.
Résumé

On a étudié la relation entre la $\mathrm{PaCO}_{2}$ et le flot de gaz frais lors de l'utilisation du circuit de Bain lors d'une césarienne. Trente et une patientes devant subir une césarienne ont été anesthésiées utilisant le circuit de Bain avec une ventilation à pression positive intermittente. La $\mathrm{PaCO}_{2}$ a été mesurée avec un flot de gaz frais $(F G F)$ de $70 \mathrm{ml} \cdot \mathrm{kg}^{-1} \cdot \mathrm{min}^{-1}, 80 \mathrm{ml} \cdot \mathrm{kg}^{-1} \cdot \mathrm{min}^{-1}$ et $100 \mathrm{ml} \cdot \mathrm{kg}^{-1} \cdot \mathrm{min}^{-1}$. Malgré une augmentation dans la production de $\mathrm{CO}_{2}$ lors de la grossesse, le flot de gaz frais requis afin de maintenir une $\mathrm{PaCO}_{2}$ donnée lors d'une césarienne demeure le même que celui requis pour des sujets nongravides. Ceci est probablement dû au fait que le flot de gaz frais est déterminé par le poids corporel. Lors d' une césarienne, le flot de gaz frais est de 15 à 20 pour cent supérieur à celui d' une femme non-gravide à cause de l'augmentation du poids associée à la grossesse. Un fot de gaz frais de $100 \mathrm{ml} \cdot \mathrm{kg}^{-1} \cdot \mathrm{min}^{-1}$ maintient une $\mathrm{PaCO}_{2}$ de $4.44 \mathrm{kPa}$ avant l'accouchement, ce qui serait la valeur désirable de la $\mathrm{PaCO}_{2}$ lors d' une césarienne. 